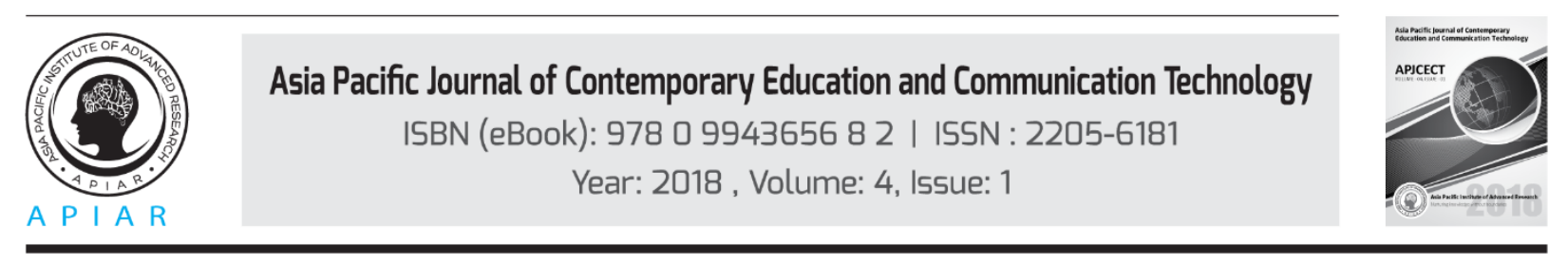

\title{
TOWARDS EFFICIENT IMPLEMENTATION OF CONTINUOUS ASSESSMENT IN ENGINEERING COURSES
}

\author{
Anas Bentamy a, Kevin Smitha b \\ ${ }^{\mathrm{ab}} \mathrm{Al}$ Akhawayn University, Ifrane, Morocco \\ Corresponding email: a.bentamy@aui.ma
}

\begin{abstract}
This study investigates the impacts on learning summative (as compared to traditional 'normal' assessment methods - midterms and final examinations) and continuous assessment (CA) methods in higher education since students' approaches to learning are greatly influenced by the assessment methods adopted. The primary goal of selecting CA was to lessen the rate of failure in typical engineering courses (Fluid Mechanics, Dynamics and Mechanics of Material) and measure its effectiveness on learning. The preliminary results reveal a drastic decrease of the number of fails in some courses. Students' perceptions about CA assessment strategy have been collected through questionnaires to better implement the CA method and to enhance the teaching effectiveness.
\end{abstract}

Keywords: Teaching, Learning, Assessment, Higher Education.

\section{Introduction and Purpose}

A short review of the literature about assessment methods indicates that assessment methods conventionally used in higher education are traditional 'normal' assessment method -written tests. Usually, students do not like conventional assessment methods, arguing that the grades do not exactly reflect their learning of course Intended Learning Outcomes. Some of them prefer multiple-choice questions known to encourage surface rather than deep learning. Others state that self- and peer-assessment in a problem-based learning environment stimulate deep learning and critical thinking (Pereiraa, D., Floresa, M. A. \& Niklasson, L., 2016). Students expect alternative assessment methods to enable a better quality of learning and to promote understanding rather than memorisation. Students' approaches to learning are then greatly influenced by the assessment methods adopted, and it has been recommended to alternate the use of normal assessment methods (Struyven, K., Dochy, F. \& Janssens, S., 2005).

The primary motivation of this work is the importance of assessing educational effectiveness. 'A Practitioner's Guide to Choice of Assessment Methods within a Module' (O’Neill, G., 2011) has been chosen as a starting point. This study aimed to explore both a) the outcomes of and b) the experiences of the students with the implementation of summative and CA methods in three engineering courses namely - Fluid Mechanics, Mechanics of Materials and Dynamics - and to strengthen good practices in student-centered learning. It is reported by Webber, K., 2012 that assessment practices based on a learner-centered assessment enhances the active involvement of the students, produce feedback, enable collaboration between students and faculty and allow teachers to realize how learning is occurring. 


\section{Context}

Al Akhawayn University (AUI) in Ifrane is a 22-year-old North American style liberal arts college in Morocco, with about 160 faculty members and 2200 students, offering bachelor and master level programs in business, science and technology, and in humanities. The vast majority of our students (95\%) come from a Moroccan high school system that is inspired by the French system, focusing on assessment through a few comprehensive exams. The characteristic difference of the North American system is its reliance on regular formative assessment throughout each phase of the study program. Students making this transition must learn different study habits, as well as approaches to prepare for and perform in this sort of formative assessment. The liberal arts pedagogy allows latitude for tailoring achievement of degree program requirements to a student's specific educational goals. The responsibility for developing a study program (university core curriculum, major and concentration courses) within the requirements lie ultimately with the individual student working in consultation with his/her advisor. Students at AUI must select majors and areas of concentration within the major (if applicable) no later than the beginning of the semester in which they enrol for the 6oth semester credit hour. Academic Advisors assist students in preparing a degree plan during the first semester and approving the course sequences.

\section{Implementation}

The engineering courses Fluid Mechanics, Mechanics of Materials and Dynamics have been taught for multiple years by the same professor using largely the same instructional approaches. They had been identified by students as very difficult courses with high failure rates. The modified assessment approach was implemented without significant change to course content or delivery approach, to ensure the validity of comparison of results between the assessment approaches.

Students were informed about the implementation of the CA method parallel to the summative assessment method during the first semester lecture this past spring 2017. As part of a continuous assessment strategy, the number of assessments has been set equal to the number of chapters covered in class. At the end of each chapter, students are evaluated by a problem-based test after having a review session through which homework and typical problems-based tests are solved. Within the summative assessment strategy, students are usually evaluated by two regular problem-based exams (commonly called mid-terms). The mid-terms are often related to 4-5 chapters covered during lectures. Students are also tested by two other assessments - a project and a comprehensive final exam - in both approaches. For the project assignment, students are required to simulate engineering problems using different programming tools and to write a short report on the specific problem analyzed which should demonstrate steps of a typical problem solving. The final grade is computed following these percentages:

Attendance

Continuous assessments or

$1^{\text {st }}$ Test and $2^{\text {nd }}$ Test

Comprehensive Final Exam Class Projects Total:
$5 \%$

$65 \%$ or

$45 \%$

$10 \%$ or

$35 \%$

20\%

$100 \%$ 
The grades for the midterms are computed by the following two means:

- The average of the continuous assessment tests. There are typically four continuous assessment tests corresponding to each midterm.

- The average of the regular midterms exam. Note that taking the midterm exam is not mandatory. This opportunity is offered to students who want to improve the grades of the average continuous assessment tests.

The variation in the percentage used for 1st Test, 2nd Test and Comprehensive Final Exam in the computation of the final grade gives additional chances to the students to improve their grades at the comprehensive final exam.

\section{Evaluation of Student Perception}

For the purpose of this study, a questionnaire addressed to 75 students was designed in order to gather the students' perception of the continuous assessment method in comparison to the summative assessment method usually implemented. Students were asked to "Approve," "Disapprove," or state no preference about a number of statements. Table 1 presents the questionnaire responses statistical results.

\begin{tabular}{|l|c|c|c|}
\hline Questions & Approve & Disapprove & No preference \\
\hline The chapter's topics on which tests are based & $84.3 \%$ & & $15.7 \%$ \\
\hline The number of tests scheduled for the semester & $89.5 \%$ & & $10.5 \%$ \\
\hline The respective dates for each test: Weekly & $15.7 \%$ & $79 \%$ & $5.3 \%$ \\
\hline The respective dates for each test: Bi-monthly & 89.5 & $10.5 \%$ & \\
\hline The respective dates for each test: Monthly & $15.7 \%$ & $73.9 \%$ & $10.4 \%$ \\
\hline Type of tests: Multiple choice (objective) tests & $36.8 \%$ & $63.2 \%$ & \\
\hline Type of tests: Structured quizzes & $47.4 \%$ & $21 \%$ & $31.6 \%$ \\
\hline Type of tests: Home assignments & $57.8 \%$ & $10.5 \%$ & $31.7 \%$ \\
\hline $\begin{array}{l}\text { C.A. strategy helps the learner to make observations } \\
\text { periodically to find out what he knows, he } \\
\text { understands and what he can do to achieve better } \\
\text { performances }\end{array}$ & $100 \%$ & & \\
\hline $\begin{array}{l}\text { C.A. strategy gives relevant information on the over- } \\
\text { all gains that a learner has made in terms of } \\
\text { knowledge, learning and skills }\end{array}$ & $84.2 \%$ & & \\
\hline $\begin{array}{l}\text { Continuous Assessment is carried out at periodic } \\
\text { intervals for the purpose of improving the overall } \\
\text { performances of learners }\end{array}$ & $94.7 \%$ & & \\
\hline Preference for C.A. & & & $5.3 \%$ \\
\hline Comments & $100 \%$ & & \\
\hline
\end{tabular}

Table 1: Questionnaire responses statistical results

The most frequent comments reported by the students are:

- more review sessions and time to prepare tests;

- too many tests in short time period but C.A method helps students to stay up-to date;

-opportunity to skip the final exam if the average of the tests is greater than 90 ;

-more and more options should be given to the students to improve their grades.

The findings show that the students perceive the CA strategy as being more effective and efficient to achieve better performance than the summative or 'normal' assessment method. This survey also demonstrates the need to consider more feedback from the students that can be 
better used to facilitate student learning, as for example a request of bi-monthly scheduled tests within a continuous assessment strategy and more and more options in the choice of assessment methods.

\section{Results}

The engineering accreditation body ABET documentation lists essential Student Outcomes (SOs) for Engineering programs, but does not specify any methodology or rubric on how to appropriately determine when achievement of a criterion has been met (Koh, M., RodriguezMarek, E. \& Talarico, C., 2009). A critical question would always be how to measure achievement of SOs from assessment of outcome-related course learning objectives. In this study, the outcome-related learning objectives of the course versus SO mapping for the three engineering courses cover ABET SOs (a), (d), (e), (f) and (k):
(a) An ability to apply knowledge of mathematics, science, and engineering;
(d) An ability to function on multi-disciplinary teams;
(e) An ability to identify, formulate, and solve engineering problems;
(f) An understanding of professional and ethical responsibility;
(k) An ability to use the techniques, skills, and modern engineering tools necessary for engineering practice.

While SOs (a), (e) and (k) are easy to relate to course learning objectives of an engineering course, SOs (d) and (f) necessitate multidisciplinary topics which should be covered in detail by alternate engineering courses.

The SO mapping had been formulated based on the content of each of these 3 engineering courses as described in the course catalogue of AUI and in the respective course syllabi. The assessment tools used are based on problem solving (exams, homework and project). An outcome-related course learning objective is directly measured from a composite of student performance on specific exam questions, homework and project, and is considered achieved by scores above $70 \%$ which also correspond to the passing grade of the overall course. The corresponding SOs can be reasonably judged as reached in this holistic approach.

Two course assessment metrics called Average and Best grade (columns 5\&6 in Tables 2-3, Appendix A \& B Tables 1-2) have been implemented to detect if a specific outcome has been achieved at least once during problem solving exams. In the Average method, the different specific assessments linked to a specific outcome are averaged for an overall score related to that outcome. In the Best grade method, the highest score on a specific assessment linked to a specific outcome is used as an indicator of achievement of that outcome.

A first reading of the course assessment matrices (Tables 2-3, Appendix A \& B Tables 1-2 ) clearly indicates a net improvement in outcomes achieved by the CA method compared to summative assessment if the Best grade method is chosen as metric. The overall improvement across all course outcomes for all courses averages $25 \%$ with this measure. Remarkable increases within the CA strategy - of SOs (a) and (e) being used substantively - in composite student performance of Mechanics of Materials, Dynamics and Fluid Mechanics are 27.6\%, 14.3\% and $29.5 \%$ respectively. If the Average grade method is chosen as metric, one obtains non-conclusive results: net increase of SO achievements (a) and (e) being used substantively - in composite student performance of Mechanics of Materials (+42\%) and notable decrease - of SO achievements (a) and (e) being used substantively - in composite student performance of Dynamics and Fluid Mechanics (-9.07\% and $-11.2 \%$ respectively). The overall improvement across all course outcomes for all courses averages $22 \%$ with this measure. 
On the other hand, the overall student's performances in terms of final grades obtained in these 3 engineering courses within the two proposed assessment methods (grade distributions are depicted on Figures 1 and Appendix A \& B figure 1 for two consecutive semesters Fall 2016 and Spring 2017) show clearly a net decrease in terms of failure (less pronounced for Dynamics). This illustrates the complexity to correlate CA strategy in terms of SOs achieved at an acceptable level with overall student performance.

\begin{tabular}{|c|c|c|c|c|c|}
\hline $\begin{array}{l}\text { Course Outcome- } \\
\text { related learning } \\
\text { objectives }\end{array}$ & $\begin{array}{l}\text { Relevant } \\
\text { ABET } \\
\text { Outcomes }\end{array}$ & Assessment & $\begin{array}{l}\text { Target: } \\
\text { composite of } \\
\text { student } \\
\text { performance }\end{array}$ & $\begin{array}{l}\text { Results } \\
\text { (Average): } \\
\text { composite of } \\
\text { student } \\
\text { performance }\end{array}$ & $\begin{array}{l}\text { Results (Best } \\
\text { grade): } \\
\text { composite of } \\
\text { student } \\
\text { performance }\end{array}$ \\
\hline $\begin{array}{l}\text { 1. Understand the } \\
\text { fundamental } \\
\text { concepts of stress and } \\
\text { strain and the } \\
\text { relationship between } \\
\text { both through the } \\
\text { strain-stress } \\
\text { equations for simple } \\
\text { tridimensional elastic } \\
\text { solids. }\end{array}$ & $\mathrm{a}(\mathrm{EAC}) 1$ & $\begin{array}{l}\text { Quiz } 1 \\
\text { Test } 1 \& \\
\text { Make up test } \\
1 \\
\text { Final Exam } \\
\text { Homework }\end{array}$ & $\begin{array}{l}80 \% \text { score } \\
7 / 10 \text { or higher }\end{array}$ & $\begin{array}{l}53 \% \text { score } \\
7 / 10 \text { or higher }\end{array}$ & $\begin{array}{l}70 \% \text { score } 7 / 10 \\
\text { or higher }\end{array}$ \\
\hline $\begin{array}{l}\text { 2. Calculate forces, } \\
\text { deflections, } \\
\text { moments, stresses, } \\
\text { and strains in a wide } \\
\text { variety of structural } \\
\text { members subjected } \\
\text { to tension, } \\
\text { compression, torsion } \\
\text { and bending. }\end{array}$ & $\begin{array}{l}\mathrm{a}(\mathrm{EAC}) 3 \\
\mathrm{e}(\mathrm{EAC}) 2\end{array}$ & $\begin{array}{l}\text { Quiz 2 \& } \\
\text { Quiz 3 } \\
\text { Test 2 } \\
\text { Final Exam } \\
\text { Homework }\end{array}$ & $\begin{array}{l}80 \% \text { score } \\
7 / 10 \text { or higher }\end{array}$ & $\begin{array}{l}29 \% \text { score } \\
7 / 10 \text { or higher }\end{array}$ & $\begin{array}{l}46 \% \text { score } 7 / 10 \\
\text { or higher }\end{array}$ \\
\hline $\begin{array}{l}\text { 3. To solve problems } \\
\text { and identify the } \\
\text { fundamental } \\
\text { elements involved in } \\
\text { the mechanical } \\
\text { design of engineering } \\
\text { structures. }\end{array}$ & $\begin{array}{l}\mathrm{a}(\mathrm{EAC}) 3 \\
\mathrm{e}(\mathrm{EAC}) 3 \\
\mathrm{f}(\mathrm{EAC}) 1\end{array}$ & $\begin{array}{l}\text { Test } 2 \\
\text { Final Exam } \\
\text { Homework }\end{array}$ & $\begin{array}{l}80 \% \text { score } \\
7 / 10 \text { or higher }\end{array}$ & $\begin{array}{l}41 \% \text { score } \\
7 / 10 \text { or higher }\end{array}$ & $\begin{array}{l}46 \% \text { score } 7 / 10 \\
\text { or higher }\end{array}$ \\
\hline $\begin{array}{l}\text { 4. Simulate } \\
\text { mechanics of } \\
\text { materials problems } \\
\text { using different } \\
\text { programming tools } \\
\text { (Java, Flash, VB or } \\
\text { Math lab). Develop } \\
\text { engineering skills } \\
\text { such as problem- } \\
\text { solving, critical } \\
\text { thinking, self- } \\
\text { learning and } \\
\text { teamwork. }\end{array}$ & $\begin{array}{l}\mathrm{a}(\mathrm{EAC}) 2 \\
\mathrm{e}(\mathrm{EAC}) 2 \\
\mathrm{~d}(\mathrm{EAC}) 3 \\
\mathrm{k}(\mathrm{EAC}) 2\end{array}$ & project & $\begin{array}{l}80 \% \text { score } \\
7 / 10 \text { or higher }\end{array}$ & $\begin{array}{l}53 \% \text { score } \\
7 / 10 \text { or higher }\end{array}$ & $\begin{array}{l}53 \% \text { score } 7 / 10 \\
\text { or higher }\end{array}$ \\
\hline
\end{tabular}

1=Objectives addresses outcome slightly, $2=$ moderately, $3=$ substantively

Table 2: Course assessment Matrix of Mechanics of Materials Fall 2016. 


\begin{tabular}{|c|c|c|c|c|c|}
\hline $\begin{array}{l}\text { Course Outcome-related } \\
\text { learning objectives }\end{array}$ & $\begin{array}{l}\text { Relevant } \\
\text { ABET } \\
\text { Outcomes }\end{array}$ & Assessment & $\begin{array}{l}\text { Target: } \\
\text { composite of } \\
\text { student } \\
\text { performance }\end{array}$ & $\begin{array}{l}\text { Results } \\
\text { (Average): } \\
\text { composite of } \\
\text { student } \\
\text { performance }\end{array}$ & $\begin{array}{l}\text { Results } \\
\text { (Best } \\
\text { grade): } \\
\text { composite of } \\
\text { student } \\
\text { performance }\end{array}$ \\
\hline $\begin{array}{l}\text { 1. Understand the } \\
\text { fundamental concepts of } \\
\text { stress and strain and the } \\
\text { relationship between } \\
\text { both through the strain- } \\
\text { stress equations for } \\
\text { simple tridimensional } \\
\text { elastic solids. }\end{array}$ & $\mathrm{a}(\mathrm{EAC})^{1}$ & $\begin{array}{l}\text { Test } 1 \\
\text { Final Exam } \\
\text { Homework }\end{array}$ & $\begin{array}{l}80 \% \text { score } \\
7 / 10 \text { or } \\
\text { higher }\end{array}$ & $\begin{array}{l}84.2 \% \text { score } \\
7 / 10 \text { or } \\
\text { higher }\end{array}$ & $\begin{array}{l}89.4 \% \text { score } \\
7 / 10 \text { or } \\
\text { higher }\end{array}$ \\
\hline $\begin{array}{l}\text { 2. Calculate forces, } \\
\text { deflections, moments, } \\
\text { stresses, and strains in a } \\
\text { wide variety of structural } \\
\text { members subjected to } \\
\text { tension, compression, } \\
\text { torsion and bending. }\end{array}$ & $\begin{array}{l}\mathrm{a}(\mathrm{EAC})^{3} \\
\mathrm{e}(\mathrm{EAC})^{2}\end{array}$ & $\begin{array}{l}\text { Test } 2 \\
\text { Final Exam } \\
\text { Homework }\end{array}$ & $\begin{array}{l}80 \% \text { score } \\
7 / 10 \text { or } \\
\text { higher }\end{array}$ & $\begin{array}{l}71 \% \text { score } \\
7 / 10 \text { or } \\
\text { higher }\end{array}$ & $\begin{array}{l}73.6 \% \text { score } \\
7 / 10 \text { or } \\
\text { higher }\end{array}$ \\
\hline $\begin{array}{l}\text { 3. To solve problems and } \\
\text { identify the fundamental } \\
\text { elements involved in the } \\
\text { mechanical design of } \\
\text { engineering structures. }\end{array}$ & $\begin{array}{l}\text { a (EAC) }{ }^{3} \\
\text { e (EAC) }{ }^{3} \\
f(E A C)^{1}\end{array}$ & $\begin{array}{l}\text { Test } 2 \\
\text { Final Exam } \\
\text { Homework }\end{array}$ & $\begin{array}{l}80 \% \text { score } \\
7 / 10 \text { or } \\
\text { higher }\end{array}$ & $\begin{array}{l}71 \% \text { score } \\
7 / 10 \text { or } \\
\text { higher }\end{array}$ & $\begin{array}{l}73.6 \% \text { score } \\
7 / 10 \text { or } \\
\text { higher }\end{array}$ \\
\hline $\begin{array}{l}\text { 4. Simulate mechanics of } \\
\text { materials problems using } \\
\text { different programming } \\
\text { tools (Java, Flash, VB or } \\
\text { Math lab). Develop } \\
\text { engineering skills such as } \\
\text { problem-solving, critical } \\
\text { thinking, self-learning } \\
\text { and teamwork. }\end{array}$ & $\begin{array}{l}\mathrm{a}(\mathrm{EAC})^{2} \\
\mathrm{e}(\mathrm{EAC})^{2} \\
\mathrm{~d}(\mathrm{EAC})^{3} \\
\mathrm{k}(\mathrm{EAC})^{2}\end{array}$ & project & $\begin{array}{l}80 \% \text { score } \\
7 / 10 \text { or } \\
\text { higher }\end{array}$ & $\begin{array}{l}78.9 \% \text { score } \\
7 / 10 \text { or } \\
\text { higher }\end{array}$ & $\begin{array}{l}78.9 \% \text { score } \\
7 / 10 \text { or } \\
\text { higher }\end{array}$ \\
\hline
\end{tabular}

${ }^{1}=$ Objectives addresses outcome slightly, ${ }^{2}=$ moderately, ${ }^{3}=$ substantively

1=Objectives addresses outcome slightly, 2=moderately, $3=$ substantively

Table 3: Course assessment Matrix of Mechanics of Materials Spring 2017.
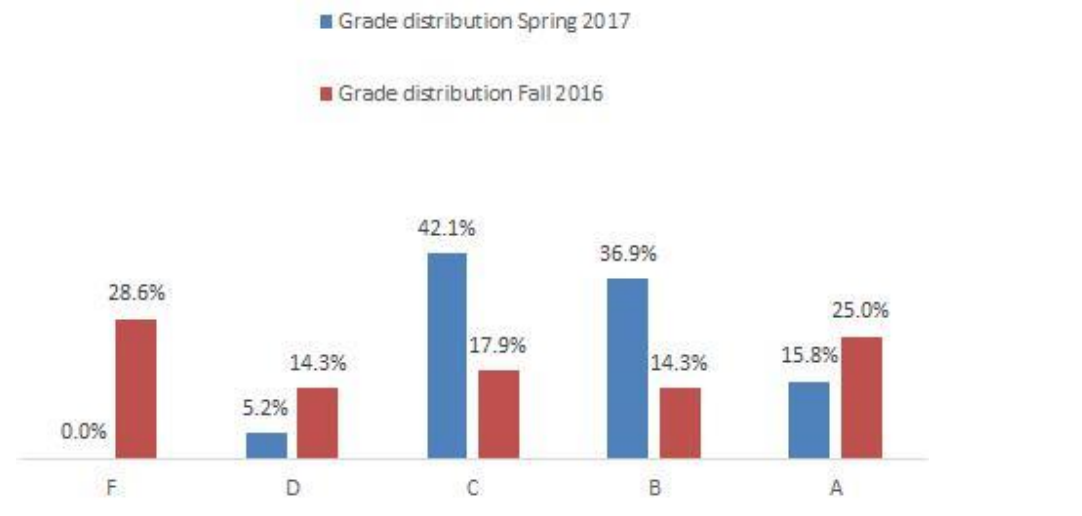

Figure 1: Grade distribution of Mechanics of Materials. 


\section{Conclusion}

The continuous assessment strategy adopted in the 3 engineering classes appears to support student learning and to increase students' motivation for learning. Measures of the Course Outcome-related learning objectives provide efficient diagnosis tools on the strengths and weaknesses for the improvement of the learning process. The following are some recommendations left for future work:

Implement measure of level of achievement of SOs - non-achievement, minimal achievement, high level achievement;

$\square$ Relevance of math skills in engineering courses: identify methodology to help students to gain sufficient competencies in math;

$\square$ Advanced implementation of problem based learning environment: insertion at different levels of SOs to be attained in homework, exams and projects;

$\square$ Extensive use of alternative assessment methods: self- and peer-assessment in a problem-based learning environment and cooperative learning for example. 


\section{References}

i. Jones A.L., 2015. A Metric for Assessment of ABET Student Outcome "b" - Experimental Design and Analyzing the Results. 122nd ASEE (American Society for Engineering Education) Annual Conference \& Exposition, 14 - 17 June Seattle, WA.

ii. Koh, M., Rodriguez-Marek, E. \& Talarico, C., 2009. Development of Course Assessment Metrics to Measure Program Outcomes Against ABET Criteria in a Digital Circuits Class. American Society for Engineering Education, AC 2009-236, pp. 14-481-1 - 14-481-14.

iii. O’Neill, G., 2011. A Practitioner's Guide to Choice of Assessment Methods within a Module, Dublin: UCD Teaching and Learning, http://www.ucd.ie/teaching/resources/assessment/howdoyouassessstudentlearning/.

iv. Pereiraa, D., Floresa, M. A. \& Niklasson, L., 2016. Assessment revisited: a review of research in Assessment and Evaluation in Higher Education. Assessment \& Evaluation in Higher Education, 41 (7), pp. 1008-1032.

v. Struyven, K., Dochy, F. \& Janssens, S., 2005. Students' perceptions about evaluation and assessment in higher education: a review. Assessment \& Evaluation in Higher Education, 30 (4), pp. 331-347.

vi. Webber, K., 2012. The Use of Learner-centered Assessment in US Colleges and Universities. Research in Higher Education, 53 (2), pp. 201-228. 


\section{Appendix A}

\section{Course assessment Matrices and Grade distribution of Dynamics (Fall 2016 and Spring 2017)}

\begin{tabular}{|c|c|c|c|c|c|}
\hline $\begin{array}{l}\text { Course Outcome- } \\
\text { related learning } \\
\text { objectives }\end{array}$ & $\begin{array}{l}\text { Relevant } \\
\text { ABET } \\
\text { Outcomes }\end{array}$ & Assessment & $\begin{array}{l}\text { Target: } \\
\text { composite of } \\
\text { student } \\
\text { performance }\end{array}$ & $\begin{array}{l}\text { Results } \\
\text { (Average): } \\
\text { composite of } \\
\text { student } \\
\text { performance }\end{array}$ & $\begin{array}{l}\text { Results } \\
\text { (Best } \\
\text { grade): } \\
\text { composite of } \\
\text { student } \\
\text { performance }\end{array}$ \\
\hline $\begin{array}{l}\text { 1. Be able to relate the } \\
\text { kinematics of particles } \\
\text { and rigid bodies to the } \\
\text { solution of dynamics } \\
\text { problems in straight } \\
\text { line and curvilinear } \\
\text { motion }\end{array}$ & $\mathrm{a}(\mathrm{EAC})_{2}$ & $\begin{array}{l}\text { Quiz } 1 \& 2 \\
\text { Test } 1 \& \\
\text { Make up test } \\
1 \\
\text { Final Exam } \\
\text { Homework }\end{array}$ & $\begin{array}{l}80 \% \text { score } \\
7 / 10 \text { or } \\
\text { higher }\end{array}$ & $\begin{array}{l}50 \% \text { score } \\
7 / 10 \text { or } \\
\text { higher }\end{array}$ & $\begin{array}{l}71.4 \% \text { score } \\
7 / 10 \text { or } \\
\text { higher }\end{array}$ \\
\hline $\begin{array}{l}\text { 2. Apply kinematics, } \\
\text { kinetic analysis, energy } \\
\text { and momentum } \\
\text { methods for particles } \\
\text { and system of particles. } \\
\text { Apply Newton's laws of } \\
\text { motion in the study of } \\
\text { particles in motion. }\end{array}$ & $\begin{array}{l}\mathrm{a}(\mathrm{EAC})_{3} \\
\mathrm{e}(\mathrm{EAC})_{2}\end{array}$ & $\begin{array}{l}\text { Test } 2 \\
\text { Final Exam } \\
\text { Homework }\end{array}$ & $\begin{array}{l}80 \% \text { score } \\
7 / 10 \text { or } \\
\text { higher }\end{array}$ & $\begin{array}{l}53.57 \% \text { score } \\
7 / 10 \text { or } \\
\text { higher }\end{array}$ & $\begin{array}{l}64.2 \% \text { score } \\
7 / 10 \text { or } \\
\text { higher }\end{array}$ \\
\hline $\begin{array}{l}\text { 3. Apply kinematics, } \\
\text { kinetic analysis, energy } \\
\text { and momentum } \\
\text { methods for rigid } \\
\text { bodies in motion } \\
\text { including mechanical } \\
\text { vibrations. }\end{array}$ & $\begin{array}{l}\mathrm{a}(\mathrm{EAC})_{3} \\
\mathrm{e}(\mathrm{EAC})_{3} \\
\mathrm{f}(\mathrm{EAC})\end{array}$ & $\begin{array}{l}\text { Test } 2 \\
\text { Final Exam } \\
\text { Homework }\end{array}$ & $\begin{array}{l}80 \% \text { score } \\
7 / 10 \text { or } \\
\text { higher }\end{array}$ & $\begin{array}{l}53.57 \% \text { score } \\
7 / 10 \text { or } \\
\text { higher }\end{array}$ & $\begin{array}{l}64.2 \% \text { score } \\
7 / 10 \text { or } \\
\text { higher }\end{array}$ \\
\hline $\begin{array}{l}\text { 4. Simulate dynamics } \\
\text { problems using } \\
\text { different programming } \\
\text { tools (Java, Flash, VB } \\
\text { or Math lab). Develop } \\
\text { engineering skills such } \\
\text { as problem-solving, } \\
\text { critical thinking, self- } \\
\text { learning and teamwork. }\end{array}$ & $\begin{array}{l}\mathrm{a}(\mathrm{EAC})_{2} \\
\mathrm{e}(\mathrm{EAC})_{2} \\
\mathrm{~d}(\mathrm{EAC})_{3} \\
\mathrm{k}(\mathrm{EAC})_{2}\end{array}$ & project & $\begin{array}{l}80 \% \text { score } \\
7 / 10 \text { or } \\
\text { higher }\end{array}$ & $\begin{array}{l}85.7 \% \text { score } \\
7 / 10 \text { or } \\
\text { higher }\end{array}$ & $\begin{array}{l}85.7 \% \text { score } \\
7 / 10 \text { or } \\
\text { higher }\end{array}$ \\
\hline
\end{tabular}

${ }_{1}=$ Objectives addresses outcome slightly, ${ }_{2}=$ moderately ${ }_{3}=$ substantively

Table 1: Course assessment Matrix of Dynamics Fall 2016. 


\begin{tabular}{|c|c|c|c|c|c|}
\hline $\begin{array}{l}\text { Course Outcome- } \\
\text { related learning } \\
\text { Objectives }\end{array}$ & $\begin{array}{l}\text { Relevant } \\
\text { ABET } \\
\text { Outcomes }\end{array}$ & Assessment & $\begin{array}{l}\text { Target: } \\
\text { composite of } \\
\text { Student } \\
\text { performance }\end{array}$ & $\begin{array}{l}\text { Results } \\
\text { (Average): } \\
\text { composite of } \\
\text { student } \\
\text { performance }\end{array}$ & $\begin{array}{l}\text { Results } \\
\text { (Best } \\
\text { grade): } \\
\text { composite of } \\
\text { student } \\
\text { performance }\end{array}$ \\
\hline $\begin{array}{l}\text { 1. Be able to relate the } \\
\text { kinematics of particles } \\
\text { and rigid bodies to the } \\
\text { solution of dynamics } \\
\text { problems in straight } \\
\text { line and curvilinear } \\
\text { motion }\end{array}$ & $\mathrm{a}(\mathrm{EAC})_{2}$ & $\begin{array}{l}\text { Test } 1 \\
\text { Final Exam } \\
\text { Homework }\end{array}$ & $\begin{array}{l}80 \% \text { score } \\
7 / 10 \text { or } \\
\text { higher }\end{array}$ & $\begin{array}{l}46.6 \% \text { score } \\
7 / 10 \text { or } \\
\text { higher }\end{array}$ & $\begin{array}{l}46.6 \% \text { score } \\
7 / 10 \text { or } \\
\text { higher }\end{array}$ \\
\hline $\begin{array}{l}\text { 2. Apply kinematics, } \\
\text { kinetic analysis, energy } \\
\text { and momentum } \\
\text { methods for particles } \\
\text { and system of particles. } \\
\text { Apply Newton's laws of } \\
\text { motion in the study of } \\
\text { particles in motion. }\end{array}$ & $\begin{array}{l}\mathrm{a}(\mathrm{EAC})_{3} \\
\mathrm{e}(\mathrm{EAC})_{2}\end{array}$ & $\begin{array}{l}\text { Test } 2 \\
\text { Final Exam } \\
\text { Homework }\end{array}$ & $\begin{array}{l}80 \% \text { score } \\
7 / 10 \text { or } \\
\text { higher }\end{array}$ & $\begin{array}{l}44.5 \% \text { score } \\
7 / 10 \text { or } \\
\text { higher }\end{array}$ & $\begin{array}{l}78.5 \% \text { score } \\
7 / 10 \text { or } \\
\text { higher }\end{array}$ \\
\hline $\begin{array}{l}\text { 3. Apply kinematics, } \\
\text { kinetic analysis, energy } \\
\text { and momentum } \\
\text { methods for rigid } \\
\text { bodies in motion } \\
\text { including mechanical } \\
\text { vibrations. }\end{array}$ & $\begin{array}{l}\mathrm{a}(\mathrm{EAC})_{3} \\
\mathrm{e}(\mathrm{EAC})_{3} \\
\mathrm{f}(\mathrm{EAC})_{1}\end{array}$ & $\begin{array}{l}\text { Test } 2 \\
\text { Final Exam } \\
\text { Homework }\end{array}$ & $\begin{array}{l}80 \% \text { score } \\
7 / 10 \text { or } \\
\text { higher }\end{array}$ & $\begin{array}{l}44.5 \% \text { score } \\
7 / 10 \text { or } \\
\text { higher }\end{array}$ & $\begin{array}{l}78.5 \% \text { score } \\
7 / 10 \text { or } \\
\text { higher }\end{array}$ \\
\hline $\begin{array}{l}\text { 4. Simulate dynamics } \\
\text { problems using } \\
\text { different programming } \\
\text { tools (Java, Flash, VB } \\
\text { or Math lab). Develop } \\
\text { engineering skills such } \\
\text { as problem-solving, } \\
\text { critical thinking, self- } \\
\text { learning and teamwork. }\end{array}$ & $\begin{array}{l}\mathrm{a}(\mathrm{EAC})_{2} \\
\mathrm{e}(\mathrm{EAC})_{2} \\
\mathrm{~d}(\mathrm{EAC})_{3} \\
\mathrm{k}(\mathrm{EAC})_{2}\end{array}$ & project & $\begin{array}{l}80 \% \text { score } \\
7 / 10 \text { or } \\
\text { higher }\end{array}$ & $\begin{array}{l}82.6 \% \text { score } \\
7 / 10 \text { or } \\
\text { higher }\end{array}$ & $\begin{array}{l}82.6 \% \text { score } \\
7 / 10 \text { or } \\
\text { higher }\end{array}$ \\
\hline
\end{tabular}
${ }_{1}=$ Objectives addresses outcome slightly, ${ }_{2}=$ moderately, ${ }_{3}=$ substantively

Table 2: Course assessment Matrix of Dynamics Spring 2017.

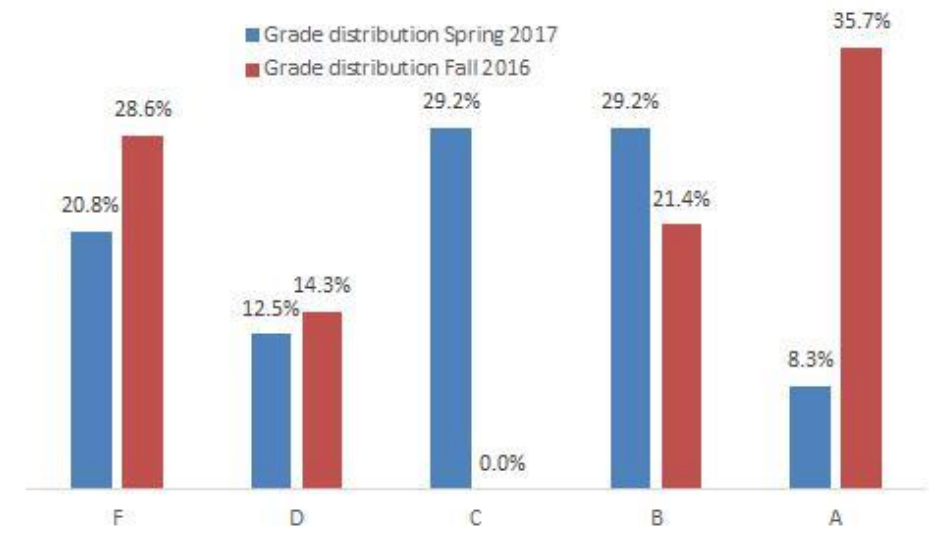

Figure 1: Grade distribution of Dynamics. 


\section{Appendix B}

\section{Course assessment Matrices and Grade distribution of Fluid Mechanics (Fall 2016 and Spring 2017)}

\begin{tabular}{|c|c|c|c|c|c|}
\hline $\begin{array}{l}\text { Course } \\
\text { Outcome-related } \\
\text { learning objectives }\end{array}$ & $\begin{array}{l}\text { Relevant } \\
\text { ABET } \\
\text { Outcomes }\end{array}$ & Assessment & $\begin{array}{l}\text { Target: } \\
\text { composite of } \\
\text { student } \\
\text { performance }\end{array}$ & $\begin{array}{l}\text { Results } \\
\text { (Average): } \\
\text { composite of } \\
\text { student } \\
\text { performance }\end{array}$ & $\begin{array}{l}\text { Results (Best } \\
\text { grade): } \\
\text { composite of } \\
\text { student } \\
\text { performance }\end{array}$ \\
\hline $\begin{array}{l}\text { 1. Overview of } \\
\text { fluid mechanics: } \\
\text { properties of } \\
\text { fluids, pressure } \\
\text { and fluid statics, } \\
\text { fluid kinematics } \\
\text { and differential } \\
\text { Analysis of Fluid } \\
\text { Flow (Navier } \\
\text { Stokes equations). }\end{array}$ & $\mathrm{a}(\mathrm{EAC})_{1}$ & $\begin{array}{l}\text { Midterm } 1 \text { \& } \\
2 \\
\text { Final Exam } \\
\text { Homework }\end{array}$ & $\begin{array}{l}80 \% \text { score } \\
7 / 10 \text { or } \\
\text { higher }\end{array}$ & $\begin{array}{l}60.1 \% \text { score } \\
7 / 10 \text { or } \\
\text { higher }\end{array}$ & $\begin{array}{l}67.8 \% \text { score } \\
7 / 10 \text { or } \\
\text { higher }\end{array}$ \\
\hline $\begin{array}{l}\text { 2. Demonstrate an } \\
\text { understanding of } \\
\text { fluid kinematics. }\end{array}$ & $\begin{array}{l}\mathrm{a}(\mathrm{EAC})_{3} \\
\mathrm{e}(\mathrm{EAC})_{1}\end{array}$ & $\begin{array}{l}\text { Midterm } 1 \\
\text { Final Exam } \\
\text { Homework }\end{array}$ & $\begin{array}{l}80 \% \text { score } \\
7 / 10 \text { or } \\
\text { higher }\end{array}$ & $\begin{array}{l}56.3 \% \text { score } \\
7 / 10 \text { or } \\
\text { higher }\end{array}$ & $\begin{array}{l}57.1 \% \text { score } \\
7 / 10 \text { or } \\
\text { higher }\end{array}$ \\
\hline $\begin{array}{l}\text { 3. Understand the } \\
\text { importance of } \\
\text { mass, Bernoulli, } \\
\text { and energy } \\
\text { equations. } \\
\text { Conduct } \\
\text { momentum } \\
\text { analysis of flow } \\
\text { systems. }\end{array}$ & $\begin{array}{l}\mathrm{a}(\mathrm{EAC})_{3} \\
\mathrm{e}(\mathrm{EAC})_{3} \\
\mathrm{f}(\mathrm{EAC})_{1}\end{array}$ & $\begin{array}{l}\text { Midterm } 2 \\
\text { Final Exam } \\
\text { Homework } \\
\text { Project }\end{array}$ & $\begin{array}{l}80 \% \text { score } \\
7 / 10 \text { or } \\
\text { higher }\end{array}$ & $\begin{array}{l}61.7 \% \text { score } \\
7 / 10 \text { or } \\
\text { higher }\end{array}$ & $\begin{array}{l}67.8 \% \text { score } \\
7 / 10 \text { or } \\
\text { higher }\end{array}$ \\
\hline $\begin{array}{l}\text { 4. Develop a } \\
\text { fundamental } \\
\text { understanding of } \\
\text { dimensional } \\
\text { analysis and } \\
\text { modeling. }\end{array}$ & $\begin{array}{l}\mathrm{a}(\mathrm{EAC})_{2} \\
\mathrm{e}(\mathrm{EAC})_{2} \\
\mathrm{~d}(\mathrm{EAC})_{3} \\
\mathrm{k}(\mathrm{EAC})_{2}\end{array}$ & $\begin{array}{l}\text { Midterm } 2 \\
\text { Homework } \\
\text { Final Exam } \\
\text { Project }\end{array}$ & $\begin{array}{l}80 \% \text { score } \\
7 / 10 \text { or } \\
\text { higher }\end{array}$ & $\begin{array}{l}61.7 \% \text { score } \\
7 / 10 \text { or } \\
\text { higher }\end{array}$ & $\begin{array}{l}70.1 \% \text { score } \\
7 / 10 \text { or } \\
\text { higher }\end{array}$ \\
\hline $\begin{array}{l}\text { 5. Develop } \\
\text { practical } \\
\text { knowledge to } \\
\text { analyze internal } \\
\text { flow and to } \\
\text { approximate } \\
\text { solutions of the } \\
\text { Navier-Stokes } \\
\text { Equations. }\end{array}$ & $\mathrm{a}(\mathrm{EAC})_{3}$ & $\begin{array}{l}\text { Midterm } 1 \text { \& } \\
2 \\
\text { Final Exam } \\
\text { Homework } \\
\text { Project }\end{array}$ & $\begin{array}{l}80 \% \text { score } \\
7 / 10 \text { or } \\
\text { higher }\end{array}$ & $\begin{array}{l}70.1 \% \text { score } \\
7 / 10 \text { or } \\
\text { higher }\end{array}$ & $\begin{array}{l}\text { 70.1\% score } \\
7 / 10 \text { or } \\
\text { higher }\end{array}$ \\
\hline
\end{tabular}

Table 1: Course assessment Matrix of Fluid Mechanics Fall 2016. 


\begin{tabular}{|c|c|c|c|c|c|}
\hline $\begin{array}{l}\text { Course Outcome- } \\
\text { related learning } \\
\text { objectives }\end{array}$ & $\begin{array}{l}\text { Relevant } \\
\text { ABET } \\
\text { Outcomes }\end{array}$ & Assessment & $\begin{array}{l}\text { Target: } \\
\text { composite of } \\
\text { student } \\
\text { performance }\end{array}$ & $\begin{array}{l}\text { Results } \\
\text { (Average): } \\
\text { composite of } \\
\text { student } \\
\text { performance }\end{array}$ & $\begin{array}{l}\text { Results } \\
\text { (Best } \\
\text { grade): } \\
\text { composite of } \\
\text { student } \\
\text { performance }\end{array}$ \\
\hline $\begin{array}{l}\text { 1. Overview of fluid } \\
\text { mechanics: } \\
\text { properties of fluids, } \\
\text { pressure and fluid } \\
\text { statics, fluid } \\
\text { kinematics and } \\
\text { differential Analysis } \\
\text { of Fluid Flow. }\end{array}$ & $\mathrm{a}(\mathrm{EAC})_{1}$ & $\begin{array}{l}\text { Midterm } 1 \\
\& 2 \\
\text { Final Exam } \\
\text { Homework }\end{array}$ & $\begin{array}{l}80 \% \text { score } 7 / 10 \\
\text { or higher }\end{array}$ & $\begin{array}{l}72 \% \text { score } \\
7 / 10 \text { or } \\
\text { higher }\end{array}$ & $\begin{array}{l}86.6 \% \text { score } \\
7 / 10 \text { or } \\
\text { higher }\end{array}$ \\
\hline $\begin{array}{l}\text { 2. Demonstrate an } \\
\text { understanding of } \\
\text { fluid kinematics. }\end{array}$ & $\begin{array}{l}\mathrm{a}(\mathrm{EAC})_{3} \\
\mathrm{e}(\mathrm{EAC})_{1}\end{array}$ & $\begin{array}{l}\text { Midterm } 1 \\
\text { Final Exam } \\
\text { Homework }\end{array}$ & $\begin{array}{l}80 \% \text { score } 7 / 10 \\
\text { or higher }\end{array}$ & $\begin{array}{l}70.9 \% \text { score } \\
7 / 10 \text { or } \\
\text { higher }\end{array}$ & $\begin{array}{l}86.6 \% \text { score } \\
7 / 10 \text { or } \\
\text { higher }\end{array}$ \\
\hline $\begin{array}{l}\text { 3. Understand the } \\
\text { importance of mass, } \\
\text { Bernoulli, and } \\
\text { energy equations. } \\
\text { Conduct momentum } \\
\text { analysis of flow } \\
\text { systems. }\end{array}$ & $\begin{array}{l}\mathrm{a}(\mathrm{EAC})_{3} \\
\mathrm{e}(\mathrm{EAC})_{3} \\
\mathrm{f}(\mathrm{EAC})_{1}\end{array}$ & $\begin{array}{l}\text { Midterm } 2 \\
\text { Final Exam } \\
\text { Homework } \\
\text { Project }\end{array}$ & $\begin{array}{l}80 \% \text { score } 7 / 10 \\
\text { or higher }\end{array}$ & $\begin{array}{l}50.5 \% \text { score } \\
7 / 10 \text { or } \\
\text { higher }\end{array}$ & $\begin{array}{l}77.7 \% \text { score } \\
7 / 10 \text { or } \\
\text { higher }\end{array}$ \\
\hline $\begin{array}{l}\text { 4. Develop a } \\
\text { fundamental } \\
\text { understanding of } \\
\text { dimensional analysis } \\
\text { and modeling. }\end{array}$ & $\begin{array}{l}\mathrm{a}(\mathrm{EAC})_{2} \\
\mathrm{e}(\mathrm{EAC})_{2} \\
\mathrm{~d}(\mathrm{EAC})_{3} \\
\mathrm{k}(\mathrm{EAC})_{2}\end{array}$ & $\begin{array}{l}\text { Midterm } 2 \\
\text { Homework } \\
\text { Final Exam } \\
\text { Project }\end{array}$ & $\begin{array}{l}80 \% \text { score } 7 / 10 \\
\text { or higher }\end{array}$ & $\begin{array}{l}50.5 \% \text { score } \\
7 / 10 \text { or } \\
\text { higher }\end{array}$ & $\begin{array}{l}77.7 \% \text { score } \\
7 / 10 \text { or } \\
\text { higher }\end{array}$ \\
\hline $\begin{array}{l}\text { 5. Develop practical } \\
\text { knowledge to } \\
\text { analyze internal flow } \\
\text { and to approximate } \\
\text { solutions of the } \\
\text { Navier-Stokes } \\
\text { Equations. }\end{array}$ & $\mathrm{a}(\mathrm{EAC})_{3}$ & $\begin{array}{l}\text { Midterm } 1 \\
\text { \& } 2 \\
\text { Final Exam } \\
\text { Homework } \\
\text { Project }\end{array}$ & $\begin{array}{l}80 \% \text { score } 7 / 10 \\
\text { or higher }\end{array}$ & $\begin{array}{l}62.9 \% \text { score } \\
7 / 10 \text { or } \\
\text { higher }\end{array}$ & $\begin{array}{l}86.6 \% \text { score } \\
7 / 10 \text { or } \\
\text { higher }\end{array}$ \\
\hline
\end{tabular}

${ }_{1}=$ Objectives addresses outcome slightly, ${ }_{2}=$ moderately, ${ }_{3}=$ substantively

Table 2: Course assessment Matrix of Fluid Mechanics Spring 2017.

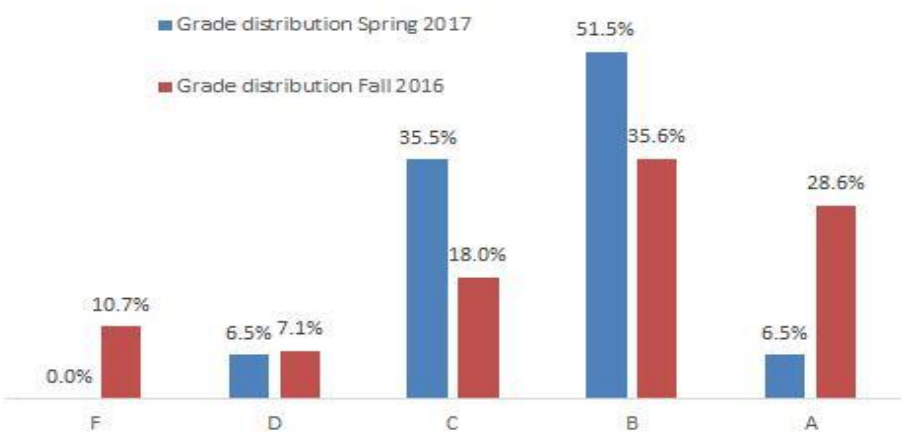

Figure 1: Grade distribution of Fluid Mechanics. 